\title{
RECOGNITION AND ENFORCEMENT OF FOREIGN JUDGMENTS IN GHANA: A SECOND LOOK AT A COLONIAL INHERITANCE
}

\author{
Richard Frimpong Oppong*
}

\section{Introduction}

Ghana was a colony of the United Kingdom. By statute it received the body of English law called private international law. Unlike other areas of law, however, the rules of private international law have not been given much attention in Ghana. The UK has reformed various aspects of the law it introduced to meet the challenges of the time: international commerce, globalisation, human rights and international law. It is, however, uncertain how Ghana is responding to these challenges.

This paper examines one aspect of these challenges, the growth of international commerce from the perspective of the rules on the recognition and enforcement of foreign money judgments in Ghana. The aim is to assess how the existing rules - common law and statutory - in Ghana are responsive to this challenge especially in the light of the present efforts by the government to promote investment and international trade.

\section{A History of Reception of English Law and the Enforcement of Foreign Judgments in Ghana}

English law was introduced into the Ghanaian legal system through the Supreme Court Ordinance of 1876. Section 14 of the Ordinance provided that:

the common law, the doctrines of equity, and Statutes of general application which were in force in England at the date when the colony obtained a local legislature, that is to say, on the 24 th of July 1874 , shall be in force within the jurisdiction of the court.

The Ordinance made the common law part of the laws of the then Gold Coast (now Ghana). Through it the body of law known as private international law, including the rules on recognition and enforcement of judgments at common law, 'became part of the laws of Ghana.

As of that date, most of the foundational principles for the recognition and enforcement of judgments at common law had been settled. ${ }^{2}$ Principles such as, that a foreign judgment created a fresh cause of action in the nature of a simple contract which could be sued

* Richard Frimpong Oppong, LLB, BL (Ghana), LLM (Cantab), LLM (Harvard). Fellow of the Cambridge Commonwealth Society. The writer is a PhD student at the University of British Columbia in Canada, and is assessing private international law issues in Africa. He thanks Mary Adjei for her support and encouragement, and can be reached at foppong2000@yahoo.com

I The existing statutes in England, such as the Crown Debts Act I80 I and the Judgment Extension Act 1868 , on the recognition and enforcement of judgments, were only of local application and did not apply to the then Gold Coast. See a discussion of the state of the law as of that time in Patchett, KW, Recognition of Commercial Judgments and Awards in the Commonwealth, 3-8, 1984, London: Butterworths.

2 Read, HE, Recognition and Enforcement of Foreign Judgments in the Common Law Units of the British Commonwealth, 52, 1938, Cambridge: Harvard University Press. 
upon as a debt, ${ }^{3}$ that the foreign judgment does not extinguish the cause of action, ${ }^{4}$ that the judgment must be for a fixed sum, ${ }^{5}$ that the judgment must be final and conclusive, ${ }^{6}$ that the courts will not review the correctness, substance or merits of the judgment, ${ }^{7}$ and that the foreign court must have been jurisdictionally competent in the English private international law sense ${ }^{8}$ had decided cases to support them.

Additionally, before 1874 , the theoretical foundation for the recognition and enforcement of foreign judgments had been laid. The theory of comity had been supplanted by the doctrine of obligation, which was to shape the evolution of the rules on this subject. The doctrine of obligation held that a foreign judgment for a fixed sum created a legal obligation that was enforceable in the English courts by an action for debt. Various principles were derived, rightly or wrongly, from this doctrine. Among these were: that the foreign judgment did not merge with the original cause of action and hence a party to that suit could bring a fresh action for the same cause by choosing not to rely of the foreign judgment; that anything that negatives the existence of the obligation is a bar to an action for the enforcement of the obligation; that it was the burden of obligees to establish the obligation for their benefit; that the foreign court must be competent in an international sense - assuming jurisdiction on a ground that the domestic court would have done is not enough; ${ }^{9}$ and that the obligation must not be variable, it must have been determined finally and conclusively.

The history of the statutory scheme for the recognition and enforcement of judgments in Ghana, on the other hand, dates back to 1907, when the Foreign Judgment Extension Ordinance 1907 No 4 was enacted. Patchett ${ }^{10}$ traces the genesis of this legislation to a complaint from a trading company in the Gold Coast to the District Commissioner about debtors who absconded to the Ivory Coast, then under French jurisdiction, ostensibly to avoid payment. The suggestion of the Company was that extradition arrangements should be instituted. The British Colonial Secretary did not respond positively to this suggestion. He was of the view that the fault lay with the traders who indiscriminately allowed credit. This response incensed the Company, which then wrote directly to the Secretary of State. They reiterated their earlier plea and further suggested that the problem existed even among the British colonies in West Africa. The Colonial Office took a second look at the matter, after an initial period of reluctance, and suggested the system of registration of judgments then in force in the UK would be a better solution. This led to the enactment of the Foreign Judgment Extension Ordinance. "I

3 Russell v Smyth (1842) 9 M\&W 810; William v Jones (1845) I3 M\&W 628.

4 Hall $v$ Odber (1809) II East II8.

5 Sedler v Robins (1808) I Camp 253.

6 Nouvion $\vee$ Freeman 15 App Cas I (1889). Although this decision came after 1874, commentary on it suggests that it only 'settled' the existing law. In the judgment Lord Watson noted that the existing authorities 'assumed' this fact. Indeed, as far back as 1843 a Canadian court had held in Gauthier v Routh (6 U.C. Q. B (OS) 602 at 607) that 'no action will lie on any but a final judgment'. See Read, above, fn 2, at 64 et al. At p 85 Read notes that 'the finality requirement is thus seen to be a corollary of the doctrine that the legal basis upon which Anglo-Dominion courts recognise "foreign judgments" at common law is that they simply recognise a foreign created right.'

7 Goddard v Gray (1870) LR 6 QB I39; Tarleton v Tarleton (1815) 4 M\&S 20.

8 Schibsby v Westenholz (I870) LR 6 QB I55.

$9 \mathrm{lbid}$.

I0 Patchett, above, fn I at 20.

II Similar legislation was made for the other colonial territories in West Africa. See Gambia: Foreign Judgment Extension Ordinance 1908 No 5; Northern Nigeria: Foreign Judgment Extension Ordinance 1908 No 2I; Southern Nigeria: Foreign Judgment Extension Ordinance 1908 No Vl; Sierra Leone: Foreign Judgment Extension Ordinance 1908 No. 4. 
This story demonstrates the link between the evolution of private international law and international commerce. ${ }^{12}$ As Justice La Forest of Canada's Supreme Court has noted, 'the rules of private international law are grounded in the need in modern times to facilitate the flow of wealth, skills and people across state lines. ${ }^{13}$ This story shows how private international law can be used to promote international commercial dealings. It also suggests that, notwithstanding the introduction of the common law in Ghana in 1876, the problem of enforcing judgments still existed even among the British colonies.

As at independence on 6 March 1957, Ghana had inherited a dual system for the recognition and enforcement of foreign judgments. There has, however, not been any comprehensive attempt to review this inheritance to bring it up to date with the challenges and demands of modern commercial dealings.

The need for a well thought through foreign judgment enforcement regime in any drive to promote international commerce and trading is self-evident. An enforcement regime that is unduly complicated, out of tune with current demands, time consuming and expensive would prove to be an obstacle to economic development since it will hamper trade relations with a country. As Caffrey notes:

The businessman wants and needs predictability, security of transaction and the prompt efficient and certain enforcement of his claims against his debtors in foreign countries. Without this security, international trade and commerce will not only not increase, it could conceivably decrease to the manifest detriment of the countries who refuse to grant this most important businessman's demand. ${ }^{14}$

To a developing country like Ghana, this should become a development concern. The need to reform the law of the recognition and enforcement of foreign judgments, inherited from the UK, in Commonwealth countries to meet current development needs was recognised at the recently held Commonwealth Ministerial Meeting in Accra, Ghana. ${ }^{15}$

In the absence of a well-developed private international law regime, businesses structure their commercial transactions to avoid as much collision as possible with specific legal systems, or at least to be able to 'control' what will happen in the event of a collision.

The resort to choice of forum and choice of law clauses is one notable device. It is not uncommon for contracts between private parties and even national governments to have choice of law and forum clauses pointing to a supposedly 'better law' or 'neutral forum' for litigation. In the words of one writer, these clauses not only serve the positive purpose of indicating the domestic law to be applied to the contract but also perform an important negative function: they are intended to shield the parties and arbitrators from the time consuming and cost-intensive uncertainties of the traditional conflict of laws doctrine. ${ }^{, 16}$

The resort to choice of law and forum clauses is often combined with the use of standard form contracts with the hope of resolving points on which the national law of the forum may be unclear or conflict with that of another forum. The goal is to reduce to the barest minimum the potential for conflict and all that it entails.

12 Sack, AN, 'Conflict of Laws in the History of English Law', in Reppy, A, (ed) LAW, A Century of Progress, 342, 1937, New York: New York University Press.

13 Morguard Investments v De Savoye [1990] 3 SCR 1077 at 1096.

I4 Caffrey, BA, 'International Jurisdiction and the Recognition and Enforcement of Foreign Judgment in the LAWASIA Region: A Comparative Survey of the Laws of Eleven ASEAN Countries Inter-se and with the EEC Countries' 6, 1985, Sydney: CCH Australia Limited.

15 Communiqué, Meeting of Commonwealth Law Ministers Accra, Ghana, 17-20 October 2005, para 38.

I6 Berger, KP, The Creeping Codification of the Lex Mercatoria, 14, 1999, Kluwer Law International. 
Another effort to avoid the rules of private international law is the resort to arbitration usually through non-state arbitral bodies in the major arbitration centres of London, New York and Paris. The belief is that arbitration offers a more flexible forum and often achieves resolution at much lower cost and in much less time. The enforcement regime under the United Nations Convention on the Recognition and Enforcement of Foreign Arbitral Awards, ${ }^{17}$ to which Ghana is a signatory, provides an added incentive for resort to arbitration because of its applicability in many countries. Additionally by engaging arbitrators who owe no allegiance to any particular State, arbitration 'allows enterprises to denationalise their dealings' 18 whilst at the same time enjoying the benefit of their disputes being resolved by experts in the area.

To a developing country like Ghana these methods of structuring commercial transactions represent a loss. They manifest a lack of faith in the legal infrastructure of the country and hence a disincentive to foreign investment. To Ghanaian businesses they entail having to hire foreign lawyers to advise, for example, on the foreign law chosen in the choice of law clause and may also imply litigation in a foreign forum at great expense. They also take work away from the Ghanaian judiciary and lawyers, thus a loss of potential foreign exchange and employment opportunities, and prevent the development of a sound body of jurisprudence in the area - a characteristic of this area of the law in Ghana.

\section{Recognition and Enforcement of Foreign Judgments in Ghana}

There are two things that judgment creditors can do with a foreign judgment. They may sue on the judgment to recover their money or plead the judgment as a defence in an action brought against them by the judgment debtor. As regards the former, there are two ways by which the foreign judgment may be recognised and enforced in Ghana. These are through an action on the judgment at common law or through a system of registration under the Courts Acts $1993^{19}$ and Instruments ${ }^{20}$ made there under.

\subsection{The common law approach}

At common law ${ }^{21}$ a judgment creditor cannot directly enforce the judgment in the judgment debtor's country. The common law deems the foreign judgment as creating an obligation, but the judgment creditor has to bring a fresh action on the judgment. The judgment creditor cannot go into direct execution. The common law treats such judgments as evidence of a debt. To be recognised and enforced the judgment has to be final and conclusive and must have been given by a court which, as a matter of Ghanaian private international law, had international jurisdiction. The fact that the judgment has to be final and conclusive raises difficult questions in the enforcement of default judgments, which are susceptible to being set aside within a certain time in most jurisdictions. However, the fact of a pending appeal

17 Convention on the Recognition and Enforcement of Arbitral Awards, New York, 10 June 1958.

I8 Juenger, FK, 'The Lex Mercatoria and Private International Law' (I999-2000) La L Rev I I33 at I I39.

19 Act 459.

20 High Court (Civil Procedure) Rules C.I. 472004 and Foreign Judgments and Maintenance Orders (Reciprocal Enforcement) Instrument 1993 (L.I. I575).

2I For a detailed treatment see Cheshire and North, Private International Law, 404-59, 1999, London: Butterworths. 
does not render a judgment inconclusive although the court in the exercise of its discretion may be slow to enforce such judgment.

A defendant to an action for recognition and enforcement may raise a number of defences. These include the absence of international competence on the part of the foreign court, breach of natural justice, fraud and inconsistency with the public policy of the enforcing forum. A distinctive future of enforcement at common law is that the court will not go into the merits or substance of the case.

The procedure in Ghana for enforcing foreign judgments is for the judgment creditor to issue a writ and plead that the judgment debt is due and owing. The party may also apply for summary judgment under Order 14 of the High Court Civil Procedure Rules ${ }^{22}$ on the grounds that the defendant has no real prospect of successfully defending the claim. The requirement of service, the time for exchange of pleadings and the actual trial imply that much time may be spent before the judgment can be enforced, especially if one factors in the backlog of cases in the Ghanaian courts. ${ }^{23}$

\subsection{Assessment of the common law approach: challenges and reform}

The common law regime for the enforcement of foreign judgments is fraught with many difficulties. Some of these difficulties date back to the 19th century when the rules of private international law as we know them today were evolving and they have survived to the present time. This section addresses some of these difficulties.

International competence: It is a fundamental requirement of the common law that a foreign judgment will be enforced only when the foreign court was internationally competent in accordance with English rules of private international law. It is not enough that the foreign court assumed jurisdiction on a ground that the domestic court would also have assumed jurisdiction, ${ }^{24}$ although occasionally it is allowed as a ground of competence. ${ }^{25}$ The common law acknowledges only two of such grounds, namely residence and submission. In the words of Cheshire and North, 'nothing else founds jurisdiction'. ${ }^{26}$ The reasoning behind these common law principles was that since the foreign judgment created an obligation it had to be shown that some relationship existed between the judgment debtor and the foreign court to merit the imposition of that obligation. The common law settled on residence and submission, although this reasoning alone did not compel that conclusion. These grounds are easy to state, but their application has produced thousands of cases and volumes of learned writing evidencing the uncertainty in this area.

A number of jurisdictions continue to debate the need to have other grounds of competence such as domicile, nationality, transacting business in the foreign forum and attachment of property. ${ }^{27}$ Rules of jurisdiction are generally rules of convenience ultimately aimed at ensuring that a judgment will not be an exercise in futility and cannot be

22 High Court Civil Procedure Rules, C.I. 472004.

23 Ghana has established a number of commercial courts to expedite trial in commercial cases.

24 Emanuel v Symon [1908] I KB 302.

25 Travers $v$ Holley [1953] 2 All ER 794. This was an action in rem involving a decree of divorce, not an in personam action.

26 Cheshire and North, above, fn 21 at 418.

27 See South African Law Reform Commission, Consolidated Legislation Relating to International Cooperation in Civil Matters, (Project I2I Discussion Paper I06) 37-45, available at http://www.law.wits.ac.za/ salc/issue/ip2I.pdf ; Tilbury, M, et al, Conflict of Laws in Australia, 2002, Oxford: Oxford University Press, 209-10. Cheshire and North, above, fn 21 at 4I8-22. 
determined by a priori reasoning. They have to accommodate changes brought about by new developments such as increased factor mobility, increasing international judicial co-operation and improvements in enforcement techniques.

In Morguard Investment Ltd v De Savoye, ${ }^{28}$ the Supreme Court of Canada undertook a re-examination of the common law rules on competence and held that a judgment from another province of $\mathrm{Canada}^{29}$ should be entitled to recognition and enforcement if the foreign court properly or appropriately exercised jurisdiction in the matter. It will be deemed to have so acted if the action had 'a real and substantial connection' with the foreign forum. The Court reasoned that comity founded on common interest, convenience, and the respect of individual rights, informs the principles of private international law. These principles are grounded in the need in modern times to facilitate the flow of wealth, skills and people across state lines in a fair and orderly manner. Consequently, what must underlie a modern system of private international law are principles of order and fairness, principles that ensure security of transactions with justice. All these considerations compel more generous grounds for the enforcement of foreign judgments.

Although the principles developed in Morguard can be criticised as vague and indeterminate, it has been extended to foreign international judgments ${ }^{30}$ and Cheshire and North have noted that 'there is much to be said for adopting the real and substantial connection test. ${ }^{31}$ It is suggested that the guiding principle for a Ghanaian court in the enforcement of foreign judgments should be that of ensuring fairness to the parties and not necessarily whether the ground for assuming jurisdiction in the foreign court fits a pre-existing ground. In an increasingly globalising world one cannot discount the importance of international judicial co-operation in the vindication of individual rights.

The judgment for fixed sum Rule: This rule is derived from the common law rule that the proper action on a foreign judgment was an action in indebitatus assumpsit. Assumpsit was a remedy used to recover on a simple contract for a sum certain. As Lord Ellenborough noted in Sadler $v$ Robins, ${ }^{32}$ the case reputed to have firmly established this rule, "the law implies a promise to pay a definite sum, not an indefinite sum.' For a foreign judgment, there may be an additional policy reason for insisting on this rule. That is it will be difficult and possibly costly for the domestic court to make an assessment that should have been made by the foreign court, which was fully seized of the facts upon which any assessment could be made.

This rule, however, takes a narrow conception of the kind of rights that can be created by a foreign judgment. A foreign judgment may create a right in rem or in personam. An in personam judgment may require the payment of money or order the doing of a thing. The fixed sum rule assumes the enforcement of only in personam judgments for the payment of money. All these rights are worthy of equal protection in an international commercial setting. In any litigation the first steps are sometimes even more important than the end result. Consequently, provisional and protective reliefs such as the Mareva injunction, ${ }^{33}$

28 (1991) 76 DLR $\left(4^{\text {th }}\right) 256$.

29 In Canada the provinces are treated for the purposes of private international law as sovereign states.

30 Beals v Saldanha [2003] 3 SCR 4I6; Parsons v McDonald's Restaurants of Canada Ltd, 250 DLR $\left(4^{\text {th }}\right)$ 224; Blom, J, 'The Enforcement of Foreign Judgments: Morguard Goes Forth Into the World' (I997) 28 Can Bus LJ 373.

31 Cheshire and North, above, fn 21 at 418.

32 Sadler v Robins ( 1808 ) I Camp 253.

33 Credit Sussie Fides Trust SA v Cuoghi [1997] 3 All ER 724; Republic of Haiti v Duvalier [1989] I All ER 456. 
Anton Piller order, ${ }^{34}$ and the anti-suit injunction, ${ }^{35}$ may need not only recognition, but also enforcement.

Although the courts are slow to order these reliefs worldwide, they are part of the reality of international commercial litigation and thus, for example, the Brussels Regulation on Jurisdiction and Enforcement of Judgments takes a broader conception of a judgment to accommodate these reliefs. ${ }^{36}$ In a recent decision of the Ontario Court of Appeal, ${ }^{37}$ the Court noted:

The time is ripe for a re-examination of the rules governing the recognition and enforcement of foreign non-monetary judgments ... However the rule is relaxed, it seems clear that a foreign judgment would have to be sufficiently certain in its terms that the [domestic] courts could enforce the judgment without having to interpret its terms or vary it.

It will be necessary, when the opportunity comes, for Ghanaian courts to expand the scope of enforceable foreign judgments to include non-money judgments.

ludgment as evidence of a debt and limitations: At common law a foreign judgment is treated as evidence of a debt. Thus the limitation period applicable to domestic debt may also apply to a foreign judgment. In Ghana this is a period of six years. ${ }^{38}$ The Limitations Decree is, however, silent on the extent of its applicability to foreign judgments. Consequently it is only by a process of reasoning thus: that Ghana's rules of private international law characterise a foreign judgment as evidence of a debt; that questions of limitations are matters of procedure for the forum; that one can conclude that the limitation period in Ghana for debts also applies to foreign judgments. This process of reasoning is, however, doubtful. For example, the UK has abandoned the common law rule, which favoured the domestic law. ${ }^{39}$ In Canada and Australia a functional approach has been adopted. ${ }^{40}$

Some have also doubted the propriety of characterising a foreign judgment as a debt and advocated it should be treated as a judgment subject to the limitation period for the enforcement of domestic judgments. In Ghana this is six years with the possibility of an extension with leave of court. The High Court (Civil Procedure) Rules provide that a writ of execution to enforce a judgment or order may not issue without leave of the court where six years or more have elapsed since the date of the judgment or order. ${ }^{4 I}$ Under the Limitations Decree 1972 'an action shall not be brought upon a judgment after the expiration of twelve years from the date on which the judgment became enforceable. ${ }^{, 42}$ This section applies to actions other than actions for execution. The section will, however, not apply to

34 Altertext Inc v Advanced Data Communication Ltd [1985] I All ER 395.

35 Turner v Grovit [200I] UKHL 65; Donohue v Armco Inc [2002] I All ER 749.

36 Article 32 of the Brussels Regulation on Jurisdiction and the Recognition and Enforcements of Judgments in Civil and Commercial Matters (Regulation 44/200I [200I] OJL I2/I) defines judgment as 'any judgment'. Compare Art 2 of the Hague Convention on the Recognition and Enforcements of Foreign Judgments in Civil and Commercial Matters, which excludes 'provisional or protective measures'.

37 Pro Swing Inc v Elta Golf Inc (2004) 7I OR (3d) 566 (leave to appeal to the Supreme Court of Canada granted March 2005). See also Oppong, R. F. Enforcing Foreign Non-money Judgments: An Examination of Some Recent Developments in Canada and Beyond (2006) 39 UBC Law Rev. (forthcoming).

38 Section 4 of Limitations Decree 1972 NRCD 54 bars actions founded on a simple contract or quasicontract after six years. However under s 5(2) 'an action shall not be brought upon a judgment after the expiration of twelve years from the date on which the judgment became enforceable.' This section will not apply to a foreign judgment until an action has been brought upon it and it is recognised and made enforceable within Ghana.

39 Foreign Limitation Periods Act 1984.

40 Tolofson v Jensen [1994] SCR 1022; John Pfeiffer Pty Ltd v Rogerson [2000] HCA 36.

$4 \mathrm{I}$ Order $44 \mathrm{r} \mathrm{I}(\mathrm{a})$.

42 Section 5(2) of the Limitations Decree, 1972 NRCD 54. 
a foreign judgment until an action has been brought upon it and it is recognised and made enforceable within Ghana.

The question of the proper characterisation of foreign judgments has come up in recent times in Canada. In Girsberger $v$ Kresz, ${ }^{43} \mathrm{Mr}$ Justice Cumming held that a foreign judgment should be characterised as a judgment and have applied to it the limitation rules applicable to domestic judgments. He reasoned that:

The law relating to the recognition and enforcement of foreign judgments has been modernized significantly in recent times to reflect the changing needs and dictates of the forces of globalization. The characterization of in personam foreign judgments must now properly reflect these new developments ... Canadian courts no longer need to continue to apply this [foreign judgment as debt] legal fiction.

This characterisation has been followed in the Alberta Court of Queen's Bench, ${ }^{44}$ but rejected by the Ontario Court of Appeal ${ }^{45}$ and the Manitoba Court of Queen's Bench. ${ }^{46}$

That this discussion is going on demonstrates a realisation of the need to readjust the inherited common law rules and bring them in line with current demands. The dictates of fairness and justice for the individual suggest that we eschew legal fictions that have outlived their purpose. As Fuller has noted, legal fictions are like the scaffolding used in the construction of a building. The scaffolding is necessary, but after the building has been erected the scaffolding serves only to obscure the building. ${ }^{47}$ The legal fiction that a foreign judgment is evidence of a debt was created to allow an action to be brought on it at a time when forms of action were a pervasive part in the evolution of the common law. That is not so now. The earlier we call a spade a spade and try to come to grips with that calling, the better it will be for us.

The non-merger rule: It has long been an established principle of the common law that a foreign judgment does not merge the original cause of action and consequently that the foreign judgment creditor has the option of suing either on the original cause of action or on the foreign judgment. Read traces the origins of this rule to the rule that the foreign court is not a court of record and submits that it is 'in complete logical disagreement with the true basis on which foreign judgments are recognised,' which is that they are recognised because they establish a foreign judicially-created substantive right. ${ }^{48}$

The rule has been criticised as having an 'illogical survival', 49 'difficult to justify in principle', ${ }^{50}$ and 'never thoroughly analysed'. ${ }^{51}$ It has been modified in the UK. Section 34 of the Civil Jurisdiction and Judgment Act 1982 provides that:

No proceedings may be brought by any person in England and Wales or Northern Ireland on a cause of action in respect of which a judgment has been given in his favour in proceedings between the same parties or their privies in a court in another part of the United Kingdom

43 (2000) 47 OR (3d) I 45 SCJ.

44 Banque Nationale de Paris (Canada) v Opiola (2000) 78 Alta LR $\left(3^{\text {rd }}\right) 92$.

45 Lax v Lax [2004] 70 OR (3d) 520.

46 Canadian Mortgage \& Housing Corp v Horsfall [2004] 185 Man LR $\left(2^{\text {nd }}\right)$ I5I. See also the South African case of Society of Lloyd's v Price 2005 (3) SA 549.

47 Fuller, L, Legal Fiction, 70, 1967, Stanford: Stanford University Press, quoting John C Gray.

48 Read, above, fn 2 at I20. See also Goodrich, HF, Handbook of the Conflict of Laws, 407, 1964, St Paul: West Publication, where he notes that the rule seems explicable on the view that such a judgment is technically a record and therefore not a security of higher nature than the original claim.

49 Carl Zeiss Stifung v Rayner [1967] AC 853 at 966 per Lord Wilberforce.

50 Goodrich, above, fn 48 at 407.

5I Piggott, F, Foreign Judgments and Jurisdiction, 17, 1908, Hong Kong: Kelly and Walsh Ltd. 
or in a court of an overseas country, unless the judgment is not enforceable or entitled to recognition in England and Wales, or, as the case may be, in Northern Ireland. ${ }^{52}$

The section demonstrates one practical utility of the rule. In cases where the judgment is not for any reason enforceable or entitled to recognition it should be possible for the aggrieved party to institute a fresh action to recover his money. As Justice Barrett once held, it is not the judgment, but the satisfaction of it, that renders it a bar to recovery in a domestic government upon the original cause of action. ${ }^{53}$ In Ghana such a situation of an unsatisfied judgment can arise in cases where the President has declared judgments from a country unenforceable in Ghana because the country does not grant favourable treatment to judgments from Ghana. ${ }^{54}$ Apart from this situation ${ }^{55}$ and in the absence of a waiver or an estoppel preventing a party from challenging the institution of fresh action, it seems unjust to allow the same issue to be litigated afresh between the same parties. ${ }^{56}$

The public policy of reducing the judicial workload to ensure the speedy adjudication of disputes militates against the rule. Consequently there is the need for a statute to modify the scope of the rule or for the judiciary, through purposive construction of the rule in the light of current demands, to limit its application to only these two instances. Indeed, as far back as 1908, the call had been made on the judiciary to 'play their part' in seeing to the abolition of the rule. ${ }^{57}$ It is gratifying to note that a similar call has been made for the clarification of the application of this rule in South Africa. ${ }^{58}$

\subsection{The statute law approach}

There is a statutory scheme for the registration of judgments in Ghana. This scheme dates back to $1908^{59}$ and is currently regulated by Part V of the Courts Act 1993 (Act 459). There is a striking resemblance between the provisions of this Act and the Foreign Judgment (Reciprocal Enforcement) Act 1933 of England. ${ }^{60}$ It operates on the basis of reciprocity. Thus, if the President is satisfied that when the benefits of the scheme are extended to judgments from a particular country similar benefits will be accorded judgments from Ghana, the President may by a legislative instrument designate such a country as entitled to the benefits of the scheme. ${ }^{61}$ The President may also by legislative instrument decree that no proceedings shall be entertained in any court in Ghana for the recovery of any sum alleged to be payable under a judgment given in a court of a country which accords less favourable treatment to judgments from Ghana. ${ }^{62}$

52 Civil Jurisdiction and Judgment Act 1982. For recent application of this section see Republic of India $v$ India Steamship Co [1998] AC 878.

53 Eastern Townships Bank v H S Beebe \& Co 53 Vt 177 at 182 (I880).

54 Section 87 of the Courts Act 1993 (Act 459). Discussed below.

55 A judgment, which is held to be unenforceable by reason of absence of jurisdiction, breach of natural justice or public policy or fraud will not fall into this situation. Indeed in such a case the rules of estoppel per rem judicatam will prevent the institution of fresh action.

56 It has been held that s 34 of the Civil Jurisdiction and Judgments Act 1982 operates as a bar against proceedings and not an exclusion of jurisdiction and hence can be defeated by a plea of waiver or estoppel. See Republic of India v India Steamship Co [1993] AC 4I0.

57 Piggott, above, fn $5 \mathrm{I}$ at 30.

58 See South African Law Reform Commission, above, fn 27 at 53-54, 70.

59 Foreign Judgment Extension Ordinance 1907 No 4.

60 The provisions of the English Act are discussed in Cheshire and North, above, fn 21 at 464-73.

6I Section 81 (I) of Act 459.

62 Section 87 of Act 459. 
The statutory scheme applies to a judgment from the designated country if it is final and conclusive between the parties and there is payable under it a sum of money not being a sum payable in respect of taxes or other charges of similar nature or in respect of a fine or penalty. A judgment is final notwithstanding that an appeal is pending or that a legal possibility exists for an appeal. ${ }^{63}$

A judgment creditor of a judgment to which the scheme applies may apply, within six years of the judgment and with proof of prescribed matters, to the High Court for registration. ${ }^{64}$ It has been held that an extension of time cannot be granted after this period. ${ }^{65} \mathrm{~A}$ right of execution exists after registration. The judgment will, however, not be registered if it has been wholly satisfied or it could not be enforced by execution in the country of the judgment. ${ }^{66}$ Additionally, where the sum payable under the judgment which is to be registered is expressed in a currency other than the currency of Ghana the judgment shall be registered as if it were a judgment for a sum in the currency of Ghana based on the rate of bank exchange prevailing at the date of the judgment of the original court. ${ }^{67}$

A person against whom a registered judgment may be enforced can apply for the registration to be set aside. There exist mandatory and discretionary grounds for setting aside the registration. The mandatory grounds are: absence of jurisdiction; non-appearance in the original proceedings due to the fact that the person was not given sufficient time to prepare a defence; fraud; and inconsistency with Ghanaian public policy. ${ }^{68}$ Among the recognised bases of jurisdiction are residence, submission, and in the case of businesses, having a principal place of business, a place of business, or an office in the foreign country.

There are also discretionary grounds for setting aside registration. First, the registration may be set aside if the registering court is satisfied that the matter in dispute in the proceedings in the original court had, prior to the date of the judgment in the original court, been the subject of a final and conclusive judgment by a court that had jurisdiction in the matter. ${ }^{69}$ This rule envisages a situation of two conflicting judgments and gives the court discretion not to register the judgment presented to it. ${ }^{70}$ Secondly, the fact that an appeal is pending or the applicant is entitled to appeal may be a ground for setting aside the registration.

The procedure for applying for registration and setting aside of the registration are dealt with in Order 7I of the Civil Procedure Rules. ${ }^{71}$ An application for registration in the High Court may be made ex parte and the judge may exercise the power of registration in chambers. The application should be supported by an affidavit deposing to specific facts. ${ }^{72}$ The judgment creditor may be required to post security for the cost of registration and any

63 Section 81 of Act 459.

64 Rule 3 of the High Court (Civil Procedure) Rules C.I. 472004.

65 Yankson v Mensah [1976] I GLR 355.

66 Section 82 of Act 459.

67 Section 82(7) of Act 459.

68 Section 81 (I) (a) of Act 459.

69 Section 8I(I) (b) of Act 459.

70 Various solutions to the recognition of conflicting judgments have been suggested. See Wolff, M, Private International Law, 263, 1962, Oxford: Claredon Press. Showlag v Mansour [1995] I AC 43I where the Privy Council held that the first in time prevails and s 34(4) of the Brussels Regulation on Jurisdiction and the Enforcement of Judgments in Civil and Commercial Matters, Council Regulation EC No 44/200I, which also adopts the first in time prevails rule. In the USA, s II 4 of the Restatement Second on Conflict of Law adopts a last in time rule.

7I High Court Civil Procedure Rules 2004 C.I. 47.

72 Order 7I Rule 3 of C.I. 47. 
proceedings which may be brought to set the registration aside. Notice of the application must be served personally on the judgment debtor who must be given a specific time within which to apply to set aside the registration. It is only after the expiration of that time that execution can be issued on the judgment so registered. Currently, the duration of this time is at the discretion of the judge, but in view of the general tenor of the legislation to ensure a speedy and cost effective means of enforcement it is not likely to be an excessively long duration. In the exercise of that discretion the judge will have to weigh the interest of both parties, having in mind the paramount constitutional 'duty to be fair and candid'. 73

Registration appears not to be a right under Act 459. Section 82(3) provides that the High Court may order the judgment to be registered subject to proof of the prescribed matters and to the provisions of the Act. It is at the discretion of the judge. It is however, unlikely that registration would be denied if all the requirements of the Act are met.

\subsection{The judiciary and the statute law approach: some decided cases}

Very few decided cases exist on this Act and its predecessors. The few that have been decided however reveal the challenge posed by private international law issues for both counsel and the courts. In Yankson $v$ Mensah, ${ }^{74}$ the applicant was a judgment creditor under an English judgment delivered on 7 March 1967. In 197I, the Courts Act, (Act 372), was enacted, Part $\mathrm{V}$ of which dealt with the registration of foreign judgments. Acting under the powers conferred by s 76 of the Act, the Chairman of the National Liberation Council made the Foreign Judgments (Reciprocal Enforcement) Instrument of $1973,^{75}$ naming among others the High Court of England as one of the courts whose judgments are entitled to registration under the Act. This Instrument which made judgments of the High Court of England registrable in Ghana was published on I June 1973, but it was deemed to have come into force at the same time as the Courts Act I97I (Act 372), that is on 22 September 197I. Under s 77 of the Act, a judgment creditor of a judgment to which the Act applies has six years to apply for registration.

In October 1973, the plaintiff registered the judgment in Ghana. The registration was, however, set aside in 1974 as being out of time. The application for registration was, no doubt, the result of counsel's misreading of the law. ${ }^{76}$ Under s 76(2) of Act 372, it was provided that the judgments to which the Act applies must be ones 'given after the coming into operation of the order directing that this Sub-Part [of the Act] shall extend to that country'. Thus, since the judgment in the instant case was given before the making of the order (ie Instrument) the Act clearly did not apply to it. Realising their mistake, counsel brought an action for the enforcement of the judgment.

Ironically, this time round it was the court that was to perpetuate the initial mistake for them! The court held that the action was not maintainable because under $\mathrm{s} 80$ of the Act no proceedings could be entertained for the recovery of a sum payable under a foreign judgment registrable in Ghana other than proceedings by way of registration, and there was no provision in Act 372 permitting the court to grant an extension of time for registration. As noted already, this was palpably wrong for the Act did not apply to the plaintiff's

73 Art 296 of the 1992 Constitution of the Republic of Ghana.

74 [1976] I GLR 355.

75 Foreign Judgments (Reciprocal Enforcement) Instrument of 1973 (L.I. 824).

76 Counsel might have sought to gain advantage from the expedited procedure of registration instead of an action for enforcement. 
judgment. The result was that the judgment creditor was left without remedy through the combined mistake of counsel and the court. ${ }^{77}$

Another illustration of the difficulty judges face with private international law issues can be found in Republic v Mallet, ex parte Braun, ${ }^{78}$ a case involving a battle for child custody. In this case a German court had previously granted custody to the mother, but the father abducted the child to Ghana. In an application for habeas corpus in Ghana, counsel for the applicant argued that the custody of the child 'has been granted to the applicant by the courts of Germany and in the circumstances the applicant is the legal custodian of the child'. Counsel for the respondent replied that:

The judgments on which the applicant relied to show that she was legally entitled to the child's custody should be ignored since they cannot be enforced in this country. Because a look at the Foreign Judgments (Reciprocal Enforcement) Instrument, 1973 (L.I. 824), would reveal that there is no reciprocity of treatment in West Germany in respect of judgments given in Ghana. ${ }^{79}$ [emphasis added]

Without realising that counsel were operating at two different levels (that is whilst one was arguing for recognition the other was arguing against enforcement), the judge bought the argument of the respondent and held that since West Germany (as it was then) was not listed in the Instrument, the judgment could not be 'recognised and enforced in this country, ${ }^{80}$ This is not wholly correct. Whilst it is true that the judgment could not be enforced by means of registration under the $A c t,{ }^{81}$ under which the Instrument was made, because it was not a judgment within the meaning of the Act and also that the Instrument did not list West Germany, the judgment, subject to the welfare principle, could have been recognised under the common law rules.

The fact that this was an application for habeas corpus might have complicated matters for the judge, but one always has to remind oneself that conflict of laws issues are all pervading:

It starts up unexpectedly in any court and in the midst of any proceedings. It may be sprung like a mine in a plain common law action, in an administrative proceeding in equity, or in a divorce case, or a bankruptcy case, in a shipping case or a matter of criminal procedure. It makes itself heard in every existing court of justice ... ${ }^{82}$

Counsel and judges must always be armed and on the look out for one does not know when it will strike!

These cases illustrate the challenges both counsel and judges face in cases involving private international law and the impact this has on innocent clients. These challenges emanate partly from the neglect of the subject not only in Ghana, but also in other places. Commenting on this state of affairs in South Africa, Leon has noted:

conflict of laws is not a subject, which commands great attention amongst South African lawyers. Indeed it occupies a modest part of the average university curriculum and is, as an

77 The judge, Edusei J, noted that this was 'hard on the plaintiff' and attributed his predicament to 'the confusion' on the part of the solicitors. [1976] I GLR 355 at 358.

78 Republic v Mallet, ex parte Braun [1975] I GLR 68.

79 lbid at 7I.

$80 \mathrm{lbid}$ at 72 .

8I Courts Act 197I (Act 372).

82 Harrison, F, Jurisprudence and the Conflict of Laws, 1919, Oxford: Clarendon Press, 102. 
academic subject, something of an unknown quantity to the older generation of practising lawyers. ${ }^{83}$

If international clients cannot be assured of reliable legal advice in this area of the law due to its neglect, it will not auger well for Ghana's efforts at promoting international commercial dealings with it.

\subsection{Assessment of the statutory scheme: challenges and reform}

Apart from these human challenges there are also problems with the statutory scheme itself. The first problem relates to the power of the President to declare that judgments from certain countries may not be enforced in the Ghanaian courts. ${ }^{84}$ It is debatable whether this power is limited to only previously designated countries which have withdrawn the favourable treatment hitherto accorded judgments from Ghana. It appears from the section that it is not so limited.

The constitutionality of this power can be questioned. It can be argued that the power to enforce judgments is a 'judicial power' that should not be subject to the control of the President. ${ }^{85}$ Indeed, the power is too sweeping. It goes to the judgment and thus it is possible for a Ghanaian citizen who obtains a judgment from a country not so recognised to be affected by this provision. It directs that no proceeding shall be entertained in any court, thus both the statutory scheme and the common law scheme are affected. Even more frightening is the fact that it is a Presidential order directed at the courts commanding them as to which action to entertain when the constitution is emphatic that the High Court has jurisdiction in 'all matters', civil and criminal.

It can also be argued that a claimant whose judgment is refused recognition on this ground has had his property rights violated. This argument rests on the principle that a judgment is property in every sense of the word. ${ }^{86}$ International human rights law and the Ghanaian constitution ${ }^{87}$ recognise the individual's right to own property and be protected from unreasonable interference with it. The Universal Declaration on Human Rights in Art $17(2)$ is very emphatic in its terms: "no one shall be arbitrarily deprived of his property. ${ }^{, 88}$ As a signatory to this Declaration, Ghana cannot make an individual's enjoyment of this right contingent on a state of affairs (the accordance of less favourable treatment to judgments from Ghana) that the individual had no hand in creating. This amounts to an arbitrary deprivation of property and the rights therein. A similar provision in an Australian legislation has been criticised as 'parochial'. ${ }^{9}$

Indeed, one must be generally worried about the role of the Executive in the enforcement scheme. The doctrine of reciprocity, upon which the statutory scheme rests, elevates a purely private claim into one of public interest such that enforcement may be denied, or at least the route to enforcement made more complicated, depending on the treatment a person's govern-

83 Leon, P S G, 'Roma non locuta est.: the Recognition and Enforcement of Foreign Judgments in South Africa' (I 983) 26 CILSA 325.

84 Section 87 of Act 459.

85 Art 125(3), 127 of the 1992 Constitution of the Republic of Ghana.

86 Brand, R, 'Recognition of Foreign Judgments as a Trade Law Issue; the Economics of Private International Law' in Bhandari, J \& Sykes, A (eds), Economic Dimensions of International Law: Comparative and Empirical Perspectives 594, 1997.

87 Article 18 of the Constitution of the Republic of Ghana, 1992.

88 Universal Declaration on Human Rights, GA Res. 217 A (III) 10 Dec 1948.

89 Section 13 of the Foreign Judgment Act 199I of Australia. Tilby, above, fn 27 at I78. 
ment accords similar judgments from the enforcing country. The need to ensure justice for the private litigant should prevail over political considerations that a party has no influence over.

The second problem relates to the provision that requires the judgment debt to be converted into Ghanaian currency. ${ }^{90}$ The exchange rate to be used is that existing at the date of the original judgment and not the date of registration. This rule is found in similar enactments in other countries. ${ }^{91}$ The judgment date conversion rule dates back to 1831 when it was held, in Scott $v$ Beaven, ${ }^{92}$ that in an action brought in England to recover the value of a given sum in Jamaican currency, upon a judgment obtained on that island, the value is that sum in sterling money that the currency would have produced according to the actual rate of exchange between Jamaica and England at the date of judgment. Other countries adopt the date of registration conversion rule. ${ }^{93}$

The merits of these approaches can be discussed. Whichever approach is adopted, the effect of the conversion rule may be of great financial significance to both parties, especially in an era of fluctuating exchange rates. It may work to the prejudice of one party. The rule appears to be a manifestation of the common law rule that a court cannot give judgment in a foreign currency. ${ }^{94}$ This rule has been abandoned in England and modified in other jurisdictions, including Ghana, ${ }^{95}$ in recognition of the hardship it can work on parties. ${ }^{96}$ The existence of this statutory rule is inconsistent with current thinking. In Australia and New Zealand, the judgment creditor is given the option to state in his application whether he wishes the judgment to be registered in the currency of the original judgment. ${ }^{97}$ The existence of this choice somehow mitigates the potential hardship that can be caused by the rule, at least from the perspective of the judgment creditor.

Another provision of interest is s 85 of the Act 459, which appears to have been taken from s 6 of the 1933 English Act. ${ }^{98}$ It provides that:

No proceedings for the recovery of a sum payable under a foreign judgment, being a judgment to which this [Act] applies other than proceedings by way of registration of the judgment, shall be entertained by any court in Ghana.

It is difficult to understand why the statutory scheme is being 'forced' on a judgment creditor to whose judgment the Act applies as the only means for recovering his money. This appears to have been the understanding of Edusei, J, in Yankson v Mensah, when he held that the procedure of issuing a writ was 'not open to' the plaintiff. ${ }^{99}$

A brief account of the genesis of the English version of this section is given in Yukon Consolidated Gold Corporation Limited v Clark. ${ }^{100}$ Greer LJ noted that it was the "first time any

90 Section 82(7) of Act 459, Order 7I Rule 3(2) of C.I. 47.

91 Section 3(4) of the Enforcement of Foreign Civil Judgment Act, Act 32 of 1988 of South Africa, s 2(3) of the Foreign Judgments (Reciprocal Enforcement) Act 1933 of the UK.

922 B \& AD 79.

93 Section 6(II) of the Australian Foreign Judgment Act 1991.

94 Manners v Pearson [1898] I Ch 58I.

95 Royal Dutch Airlines (KLM) v Farmex Ltd [1989-90] I GLR 46.

96 Miliangos v George Frank (Textiles) Ltd [1976] AC 443; Barclays Bank of Swaziland Ltd v Mnyeketi 1992(2) SA 425.

97 Section 6(II)(a) of the Foreign Judgment Act 199I of Australia; s 4(3) of the Reciprocal Enforcement of Judgment Act 1934 of New Zealand.

98 That section provided that 'no proceedings for the payment of a sum payable under a foreign judgment to which this Part of this Act applies, other than proceedings by way of registration of the judgment, shall be entertained by any court in the United Kingdom.'

99 [1976] I GLR 355.

$100[1938] 2 \mathrm{~KB} 24 \mathrm{I}$ at 253. 
restriction was placed upon the right of anyone to say that a foreign judgment created a debt which could be enforced in this country. ${ }^{101}$ He further noted that the section was introduced:

because the foreign countries with which we entered into negotiations required that it should be so provided in order to obtain their agreement to a convention with regard to the reciprocal obligation of this country and the foreign country for the enforcement of the judgment. $^{102}$

Thus the origin of the section was contingent on the demands of the time, and need not necessarily be made to apply now. A number of common law jurisdictions in Canada allow the judgment creditor the option of registration or suing on the judgment. ${ }^{103}$

Given the current judicial workload it is possible to argue, from a public policy perspective, that it is meant to compel the judgment creditor to take the course that will involve the least amount of judicial work. This provision appears to be founded on the common law rule that the cause of action survives the foreign judgment. Consequently, although the claimant is barred from proceeding to recover his money other than by registration, he could sue on the original cause of action in Ghana. ${ }^{104}$ While there is no empirical evidence to support the former argument, the latter argument ignores the fact that the Ghanaian courts may not have jurisdiction over the cause of action and also the cost implications for the claimant.

The judgment creditor may have good 'private' reasons for not preferring to use the statutory scheme even if the judgment qualifies. For example, the judgment may contain parts to which the scheme does not apply and the judgment creditor may want to consolidate the action rather than splitting it. The creditor may also want to apply for summary judgment, which is an equally expeditious means of securing judgment and enforcement. ${ }^{105}$ By resorting to this procedure also, the judgment creditor may be able to avoid posting security for costs since the defendant will have to make an application for that. ${ }^{106}$ The judgment creditor may also want to avoid the mandatory currency conversion rule under the statutory scheme and to explore the possibility of convincing the judge to follow the current common law approach. As has been held in Ghana, there is no legal impediment in Ghana to the award of damages in foreign currency in appropriate cases. ${ }^{107}$ In international commercial dealing the availability and possibility of exploring options is an asset. Section 85 appears to deny this.

I0I [1938] 2 KB 24I at 253-54. No such provision was contained in the Administration of Justice Act 1920 which dealt with similar matters.

102 [1938] 2 KB 24I at 253.

103 Section 8 of the Reciprocal Enforcement of Judgment Act 1990 of Ontario, and s 7 of the Reciprocal Enforcement of Judgment Act 2000 of Alberta. The Alberta Act gives the judgment creditor the right to bring action 'on the original cause of action'. Section 10 of the Reciprocal Enforcement of Judgment Act 1996 of Saskatchewan.

104 Cheshire and North, commenting on section 6 of the English 1933 Act, suggest this possibility when they noted that the provision prevented the claimant from bringing an enforcement action at common law although it did not prevent him from suing on the original cause of action. Cheshire and North, above, fn $2 \mathrm{I}$ at $47 \mathrm{I}$. Section 7 of the Reciprocal Enforcement of Judgment Act 2000 of Alberta. The Alberta Act gives the judgment creditor the right to bring action 'on the original cause of action'.

105 Order I4 of C.I. 47.

106 Order 24 of C.I. 47.

107 Royal Dutch Airlines (KLM) v Farmex Ltd [1989-90] I GLR 46. 
Thirdly, the fact that the statutory scheme applies to only judgments 'for the payment of a sum of money ${ }^{108}$ is unnecessarily restrictive. ${ }^{109}$ In modern international commercial litigation various types of reliefs granted, especially before litigation, may need enforcement in a foreign forum to protect the business interest. Freezing injunctions, anti-suit injunctions, Anton Piller orders and orders for disclosure of evidence are examples of such reliefs. These provisional and protective reliefs perform various functions for the international commercial litigant. ${ }^{10}$ They enable the litigant to maintain the status quo during the litigation and ensure there will be assets to satisfy any subsequent judgment. Also, one cannot discount their tactical deployment to obtain a settlement or an abandonment of the litigation.

The international commercial litigant may want to have these reliefs recognised and enforced in Ghana by taking advantage of the expedited procedure under the statutory scheme. Indeed, with these reliefs time is usually of the essence. It is thus strange that where time is needed most, the opportunity for that is denied. Other common law jurisdictions have not been content with this restrictive approach. Jurisdictions such as New Zealand and Australia have a broader conception of judgment. Under the Australian Foreign Judgment Act 1991, judgment includes, 'a final or interlocutory order given or made by a court in civil proceedings', II and provision is made for the possibility of registering such judgments. II2

Finally, the statutory scheme does not exclude the application of the common law, and one may doubt whether it can. Thus, some of the difficulties identified for the common law regime may still be present. The grounds for setting aside registration, such as breach of natural justice, absence of jurisdiction fraud and inconsistency with public policy, cannot be meaningfully understood outside the framework of the common law. Unfortunately the common law does not speak with a common voice of these issues and even more troubling is that the Ghanaian courts have not spoken much on these issues so no one knows for sure what they will say. For the international commercial businessperson this state of uncertainty is no good news at all.

\section{Litigating Under Common Law and Statute Law Approaches}

Both the common law and the statute law schemes have their own merits and demerits for the litigant. The practice of combining both approaches, however, is very much a part of the common law world. For a private litigant, knowing which regime is applicable or available to him is of great significance since the differences in each approach have varied implications for the time and cost of litigation.

The statute law scheme, unlike the common law, presumes that the domestic court has jurisdiction over the judgment debtor. ${ }^{1 / 3}$ As the High Court of Australia noted in

108 Section 99 of Act 459.

$109 \mathrm{It}$ is suggested that the courts adopt a purposive interpretation of this provision and not the strict common law rule of judgment for a fixed sum.

I 10 Maher, G and Rodger, B J, 'Provisional and Protective Remedy: the British Experience of the Brussels Convention' (I999) 48 ICLQ 302.

I I I Section 3 of the Australian Foreign Judgment Act 1991.

I I 2 Section 5(6) and (7) of the Australian Foreign Judgment Act 199I; s 3B of the Reciprocal Enforcement of Judgment Act 1934 of New Zealand.

II 3 Thus, it is not a condition for registration that the judgment creditor establishes that the courts have jurisdiction. Neither is the absence of jurisdiction of the domestic court listed as one of the grounds for setting aside the registration. 
Hunt v BP Exploration Co (Libya) Ltd, 'the application for registration does not involve an action in personam requiring service of the Supreme Court's process in or outside the jurisdiction.' 14 This is not only a procedural advantage to the judgment creditor, but also a cost saving one. At common law the judgment creditor must establish that the domestic court has jurisdiction over the judgment debtor by serving process on the judgment debtor. This entails cost and potential delay in enforcement. The judgment creditor also need not prove the competence of the foreign court before the judgment is registered.

Additionally, the grounds of international competence under the statutory scheme $^{115}$ appears broader than is traditionally accepted under the common law. However, the courts have taken a strict view of these expanded grounds and held that the foreign judgments, which could be registered, are those coming under the specified grounds. Consequently, registration will be set aside upon proof of non-satisfaction of the specified grounds even if the grounds upon which the foreign court took jurisdiction might have been effective at common law. ${ }^{16}$ To the judgment creditor this is both an advantage and disadvantage. It reduces the scope within which the judgment debtor can apply for the registration to be set aside on grounds of want of jurisdiction. In the event the registration is set aside for want of jurisdiction, the judgment creditor is likely to go without remedy because s 85 of the Courts Act 1993 is a bar against recovering the sum payable through any other proceedings. ${ }^{117}$ It may be argued that the non-merger rule is not abolished by the Court Acts 1993 in instances where an attempt at registration of the foreign judgment fails and therefore the judgment creditor can bring a fresh action on the original cause of action; any attempt to re-litigate the original cause of action may however be met by the judgment debtor with a plea of abuse of process of the court and estoppel.

For a judgment creditor one disadvantage with the common law regime, apart from the fact of bringing a fresh action, is its proof requirements. The burden is on the judgment creditor to prove that the requirements for recognition and enforcement have been met and the action can be dismissed if the judgment creditor is unable to satisfy the requirements. In Ghana there is no presumption of conclusiveness in the creditor's favour. This approach can be contrasted with that of Tanzania. Under s II of Tanzania's Civil Procedure Code 1966, 'a foreign judgment shall be conclusive as to any matter thereby directly adjudicated upon between that same parties or between parties under whom they or any of them claim ... 118 The presumption shifts the burden of proof, with the cost it entails, onto the judgment debtor. 19

In general, the statutory scheme provides a cost effective, expedited and less technical means of enforcing foreign judgments. These considerations are paramount to all those transacting business across national boundaries where the potential for dispute and litigation exists. These advantages however pale into insignificance when one considers the effect of the reciprocity requirement under the scheme and the fact that very few

II (1980) I44 CLR 565 at 573.

II 5 Section 83 of the Courts Act 1993 (Act 459).

II 6 Societe Cooperative Sidmetal v Titan International Ltd [1966] I QB 828.

II7 Yankon v Mensah [1976] I GLR 355

118 See a discussion of this provision in Thanawalla, S, 'Foreign Inter Partes Judgments: Their Recognition and Enforcement in the Private International Law of East Africa' (1970) I9 ICLQ 430.

II 9 This presumption is, however, rebuttable by proof of want of jurisdiction, fraud, breach of natural justice, a law in force in Tanzania or international law and the fact that the judgment was not given on the merits. See ss II and I2 of the Civil Procedure Code 1966. 
countries $^{120}$ have been named as beneficiaries. Added to this limitation is the fact that only judgments from named courts in the beneficiary country can be registered under the scheme. $^{121}$

It may even be argued that the judgments from the named courts must be in the exercise of their original jurisdiction. This is because, under s 8I (2), the Act applies only to judgments from the named court, 'other than a judgment of the court given on appeal from a court which is not a [named] court'. If this interpretation is right, then further limitation is placed on the applicability of the statutory scheme. The rationale for this restriction is difficult to find. What is certain is that that rule was taken from the 1933 English Act. ${ }^{122}$ It does not appear in similar enactments in other common law jurisdictions. ${ }^{123}$ These limitations mean that the majority of judgments in Ghana will have to be enforced using the common law approach.

\section{Conclusion}

This article has examined the state of the private international law regime on the recognition and enforcement of foreign judgments in Ghana and the ability of the regime to meet the challenges of modern international commerce. A number of shortfalls have been identified. The task of reforming the law in this area is on the legislature, the judiciary and Ghanaian academics. The judiciary should be at the forefront of this reform agenda as it has historically been in the evolution of private international law rules in other jurisdictions. A careful attempt should be made in the reform efforts to reconcile the interests of the state, judgment creditor and judgment debtor. The ultimate goal should be to ensure that the rules developed will facilitate and enhance international commercial dealings with Ghana. Unless this is done international investor confidence in our legal infrastructure will be adversely affected, and the drive to promote trade and commerce with Ghana will be an exercise in futility.

The time to act is now.

I 20 These countries are Brazil, France, Israel, Italy, Japan, Lebanon, Senegal, Spain, United Arab Republic and UK. First Schedule of Foreign Judgments and Maintenance Orders (Reciprocal Enforcement) Instrument 1993 (L.I. I575).

I2I Section 8I(I)(b) of Courts Act 1993 (Act 459) and First Schedule of Foreign Judgments and Maintenance Orders (Reciprocal Enforcement) Instrument, 1993 (L.I. I575).

I 22 Section I(2) of the Foreign Judgments (Reciprocal Enforcement) Act I 933 of the UK.

I23 The Australian Foreign Judgment Act I99I. 